Microbial Discovery Research Unit, School of Biomolecular and Biomedical Sciences, Griffith University, Nathan, Brisbane, Australia 4111

\section{Development of fluorescent adjacent hybridization probes and their application in real-time PCR for the simultaneous detection and identification of Fervidobacterium and Caloramator}

\author{
Geoffrey R. Connolly and Bharat K. C. Patel \\ Author for correspondence: Bharat Patel. Tel: +61 438173 185. Fax: +61 738757800 . \\ e-mail: bharat@genomes.sci.gu.edu.au
}

\begin{abstract}
A stretch of nucleotides consisting of a conserved region and an adjacent upstream variable region in the 165 rDNA of members of domain Bacteria was identified as a suitable target site for developing a real-time PCR adjacent hybridization assay. A single universal fluorogenic cyanin 5-labelled probe, CY5 $1046+$, targeting the conserved region, and two FITC-labelled probes, Calo and Fervi, targeting the variable region were designed and synthesized for the identification and differentiation of the thermophilic anaerobes Caloramator and Fervidobacterium. The simultaneous hybridization of probes CY5 1046+ and Fervi to the 16S rDNA target sites of Fervidobacterium species during PCR amplification resulted in an increase in fluorescence emission that was monitored continuously in a LightCycler. The differences in the temperature of disassociation of the hybridization probes $\left(T_{m}\right)$ due to compositional variation in the nucleotide bases of the probe and target sequences enabled Fervidobacterium islandicum DSM $5733^{\top}$ to be differentiated from Fervidobacterium gondwanense ACM $5017^{\top}$ and Fervidobacterium nodosum ATCC $35602^{\top}$. The simultaneous hybridization of probes CY5 1046+ and Calo to the 165 rDNA target sequence of Caloramator indicus ACM $3982^{\top}$ during PCR amplification also resulted in an increase in fluorescence emission. However, as the target sequence of $C$. indicus $A C M \quad 3982^{\top}$ is identical to those of the other three Caloramator species, Caloramator fervidus ATCC 43204' (formerly Clostridium fervidus), Caloramator proteoclasticus DSM $10124^{\top}$ and Caloramator coolhaasii DSM 12679', further species discrimination on the basis of $T_{m}$ will not be possible, making probe Calo a useful genus-specific probe. The devised method was subsequently used to detect and identify Fervidobacterium and Caloramator isolates from our previously uncharacterized culture collection and from enrichment cultures. The assay is cheap and flexible, as only a battery of inexpensive FITC probes for differentiating other members of domain Bacteria needs to be synthesized and DNA templates prepared by a simple lyse-boil method, in addition to purified DNA, can also be used.
\end{abstract}

Keywords: Great Artesian Basin of Australia, thermophilic anaerobes, 16S rDNA, real-time PCR, fluorescent adjacent hybridization probes 


\section{INTRODUCTION}

The advent of molecular biology techniques such as PCR and automated sequencing of 16S rRNA genes has revolutionized our understanding of microbial diversity, with evidence suggesting that $90-99 \%$ of microbes from any given environment remain uncultured (Amann et al., 1995). Natural and man-made environments including volcanic ecosystems, subsurface environments such as oilfields and aquifers, thermal spas and compost ecosystems (Reysenbach et al., 1994; Harmsen et al., 1997; Ravot et al., 1995; Andrews \& Patel, 1996; Chrisostomos et al., 1996) have an enormous wealth of thermophilic microbes that has remained untapped. Micro-organisms from such environments are of great interest as they not only represent ancient lineages in the tree of life (Winker \& Woese, 1991) but also possess biotechnologically important thermostable enzymes (Wynter et al., 1995, 1996). The challenge now is to culture these microbes in the laboratory. It is evident that the current enrichment and isolation techniques are biased towards fast-growing microbial populations that potentially out-compete novel groups such as the slowgrowing populations (Dunbar et al., 1997). Initiating enrichment cultures under a wide variety of growth parameters should be an important procedure for discovering novel groups of thermophilic microbes, but this has been largely overlooked because of technical difficulties associated with handling the large numbers of cultures generated from such a process. Consequently, simple, specific and rapid detection and identification methods for species differentiation from enrichment cultures need to be developed. A powerful method, termed whole-cell hybridization, which relies on the use of extensive 16S rRNA sequence database resources for devising probes, can be used for such studies but is time-consuming to perform (Amann et al., 1995). The application of real-time PCR for identifying microbes is an alternative complementary method to whole-cell hybridization but has not attracted a great deal of attention. During real-time PCR, an increase in fluorescence due to the hybridization of fluorescently labelled DNA probes to complementary targets in DNA amplicons is measured. We have recently reported the use of real-time PCR assays targeting the rRNA genes for the simultaneous detection, identification, quantification and differentiation of members of Leptospira and Leptonema (Woo et al., 1997, 1998a, b) using a LightCycler (Idaho Technology, Idaho Falls, ID, USA). The LightCycler is an air thermal cycler with a built-in fluorimeter and has the ability to generate rapid thermal transitions resulting from a circulating air vortex (Wittwer et al., 1997). We report in this paper the identification of a 16S rDNA target region suitable for the development of fluorescent adjacent hybridization probes and its application in the real-time detection of the thermoanaerobic genera Fervidobacterium and Caloramator in pure and enrichment cultures.

\section{METHODS}

Source of cultures and DNA extraction. Table 1 lists the pure cultures and enrichment cultures and their sources. Type cultures were purchased from the DSMZ, the ATCC and the Australian Collection of Microorganisms (ACM). Thermophilic cultures, isolated from the Great Artesian Basin of Australia and maintained at $-80^{\circ} \mathrm{C}$ at the Microbial Technology Culture Collection (MTCC), Griffith University, were resuscitated (Patel et al., 1991; Andrews \& Patel, 1996; Ravot et al., 1995; Wynter et al., 1995, 1996). Water, sediment and microbial mat samples used for initiating enrichment cultures were collected from two bores of the Great Artesian Basin, registration numbers 17263 (Terrick Terrick) and 132, and their run-off channels as described previously (Denman et al., 1991; Patel et al., 1991; Andrews \& Patel, 1996). All cultures were grown in anaerobic Trypticase/yeast extract/glucose (TYEG) medium (Patel et al., $1985 \mathrm{a}, \mathrm{b}$ ) for up to $48 \mathrm{~h}$ at between 55 and $70{ }^{\circ} \mathrm{C}$ as indicated (Table 1).

Crude DNA was extracted from $10 \mathrm{ml}$ cultures by washing and resuspending centrifuged cell pellets in $10 \mathrm{mM}$ Tris/HCl (pH 8.0) containing $0.75 \mathrm{mg}$ each of achromopeptidase and lysozyme $\mathrm{ml}^{-1}$, followed by an incubation at $37^{\circ} \mathrm{C}$ for $20 \mathrm{~min}$. The samples were then heated for $15 \mathrm{~min}$ at $95^{\circ} \mathrm{C}$ and debris was removed by centrifugation. Cell lysis during the procedure was determined by examining aliquots from different steps and time intervals under a phase-contrast microscope. The hexadecyltrimethyl ammonium bromide (CTAB) method was used to prepare pure DNA (Wilson, 1987).

Design of primers and adjacent hybridization probes. Representative 16S rRNA gene sequences of 2000 members of the various phyla of the domain Bacteria were extracted from the GenBank database, release 125 (Benson et al., 2000), and from the Ribosomal Database Project (RDP) version 8.1 (Maidak et al., 2001) and aligned as described previously (Andrews \& Patel, 1996). Primers and probes against useful target regions were determined and their usefulness in real-time PCR assays was checked by using a set of criteria and guidelines recommended by Idaho Technology as described previously (Woo et al., 1997, $1998 \mathrm{a}, \mathrm{b})$. The most specific and ideal probe candidates for identifying members of the genera Caloramator and Fervidobacterium were confirmed by BLAST analysis and from $T_{\mathrm{m}}$ calculations. The melting temperatures $\left(T_{\mathrm{m}}\right)$ of the probes were estimated on the basis of thermodynamic data of base pairing by using a website-based calculator (http://alces. med.umn.edu/rawtm.html). The propensity of the probes to self-anneal and to anneal to the PCR amplification primers was predicted by the Oligo Selection program (Hillier \& Green, 1991). The probe and primer target nucleotide positions are reported using the Escherichia coli numbering scheme (Winker \& Woese, 1991). The probes and primers were synthesized by Genset Pacific (formerly Pacific Oligos) Pty Ltd, Lismore, Australia.

Rapid-cycle PCR and continuous monitoring of product. The monitoring of fluorescence emission during PCR was performed in a LightCycler, which is an air thermal cycler with a built-in fluorimeter. A $10-\mu \mathrm{l}$ PCR contained $0.5 \mu \mathrm{M}$ primers F1 and R5, 2 ng purified genomic DNA (or less for DNA template prepared by the boiling method), $0.2 \mathrm{mM}$ dNTPs, $3 \mathrm{mM} \mathrm{MgCl}{ }_{2}, 50 \mathrm{mM}$ Tris/ $\mathrm{HCl}(\mathrm{pH} \mathrm{8.3)}, 0.25 \mathrm{mg}$ BSA ml ${ }^{-1}$ (Sigma A2153), 0.4 U Taq DNA polymerase (Promega), 0.2 $\mu \mathrm{M}$ cyanin 5 (Cy5)-labelled universal probe 
Table 1. Thermophilic, anaerobic cultures/enrichments used in this study

All cultures were grown in pre-reduced anaerobic TYEG medium as described in Methods. Type cultures were incubated at $65^{\circ} \mathrm{C}$. Unidentified isolates were incubated at the temperatures indicated in parentheses for up to $24 \mathrm{~h}$. Enrichment cultures were incubated for $48 \mathrm{~h}$ at $60^{\circ} \mathrm{C}$ and examined microscopically for growth and cell morphology. The probe $T_{\mathrm{m}}$ values were determined from at least three independent assays. Type cultures used as negative controls included Thermoanaerobacter

thermohydrosulfuricus ATCC 35947 ${ }^{\mathrm{T}}$, Dictyoglomus thermophilum DSM 567 ${ }^{\mathrm{T}}$ and E. coli K12. RN, Registered number of the bore; ND, not determined; NG, no growth.

\begin{tabular}{|c|c|c|c|c|}
\hline \multirow[t]{2}{*}{ Strain designation/morphology } & \multirow[t]{2}{*}{ Sample type and source/reference } & \multicolumn{2}{|c|}{ Probe used } & \multirow{2}{*}{$\begin{array}{c}\text { Probe } T_{\mathrm{m}} \\
\quad\left({ }^{\circ} \mathrm{C}\right)\end{array}$} \\
\hline & & Fervi & Calo & \\
\hline \multicolumn{5}{|l|}{ Type cultures } \\
\hline \multicolumn{5}{|l|}{ Genus Fervidobacterium } \\
\hline F. nodosum ATCC $35602^{\mathrm{T}}$ & Patel et al. (1985b) & + & - & $55 \cdot 8 \pm 1 \cdot 7$ \\
\hline F. gondwanense ACM 5017 & Andrews \& Patel (1996) & + & - & $55 \cdot 5 \pm 1 \cdot 7$ \\
\hline F. islandicum DSM $5733^{\mathrm{T}}$ & Huber et al. (1990) & + & - & $61 \cdot 7 \pm 0 \cdot 5$ \\
\hline \multicolumn{5}{|l|}{ Genus Caloramator } \\
\hline C. indicus ACM $3982^{\mathrm{T}}$ & Chrisostomos et al. (1996) & - & + & $66 \pm 2 \cdot 0$ \\
\hline \multicolumn{5}{|l|}{ Unidentified cultures } \\
\hline $\mathrm{MTCC}$ AB11B $\left(65^{\circ} \mathrm{C}\right)$ & RN 4164, Orange mats, $66^{\circ} \mathrm{C}$ & - & - & - \\
\hline MTCC AB17 $\left(65^{\circ} \mathrm{C}\right)$ & RN 3034, Orange mats, $65^{\circ} \mathrm{C}$ & - & - & - \\
\hline $\operatorname{MTCC}$ AB18 $\left(70^{\circ} \mathrm{C}\right)$ & RN 3034, Below source, $70^{\circ} \mathrm{C}$ & + & - & $54 \cdot 4 \pm 0 \cdot 5$ \\
\hline MTCC AB19 $\left(65^{\circ} \mathrm{C}\right)$ & $\mathrm{RN} 3034,64^{\circ} \mathrm{C}$ & + & - & $54 \cdot 4 \pm 1 \cdot 0$ \\
\hline MTCC AB20 $\left(55^{\circ} \mathrm{C}\right)$ & RN 3034, Green mats, $53{ }^{\circ} \mathrm{C}$ & + & - & $54 \cdot 4 \pm 0 \cdot 1$ \\
\hline MTCC AB23 $\left(50^{\circ} \mathrm{C}\right)$ & RN 5142, Thick mats, $47^{\circ} \mathrm{C}$ & - & - & - \\
\hline MTCC AB31 $\left(70^{\circ} \mathrm{C}\right)$ & RN 94, Yellow mats, $70^{\circ} \mathrm{C}$ & - & - & - \\
\hline MTCC SG58 $\left(55^{\circ} \mathrm{C}\right)$ & RN 37, Microbial mat, $54^{\circ} \mathrm{C}$ & + & - & 55 \\
\hline MTCC SG59 $\left(55^{\circ} \mathrm{C}\right)$ & RN 37, Floating mat, $52^{\circ} \mathrm{C}$ & - & ND & - \\
\hline MTC SG60 $\left(55^{\circ} \mathrm{C}\right)$ & RN 37, Sediment, $52^{\circ} \mathrm{C}$ & ND & - & - \\
\hline MTCC SG64 $\left(60^{\circ} \mathrm{C}\right)$ & RN 127, Sediment, $59^{\circ} \mathrm{C}$ & $\mathrm{ND}$ & + & $67 \cdot 1$ \\
\hline MTCC $75-2\left(65^{\circ} \mathrm{C}\right)$ & RN 132, Sample B & ND & - & - \\
\hline MTCC SG76 $\left(65^{\circ} \mathrm{C}\right)$ & RN 132, Sample C & - & + & $66 \pm 1 \cdot 0$ \\
\hline MTCC SG80 $\left(65^{\circ} \mathrm{C}\right)$ & RN 89, Yellow/green mats & + & + & $54 \cdot 5$ and $67 \cdot 1$ \\
\hline \multicolumn{5}{|c|}{ Enrichment cultures from RN 17263} \\
\hline Small rods & Bore source, water sample $\mathrm{A}, 88^{\circ} \mathrm{C}$ & - & - & - \\
\hline Rods & Middle of run-off channel, sediment sample $\mathrm{D}, 75^{\circ} \mathrm{C}$ & - & - & - \\
\hline Rods & Side of run-off channel, sediment sample $\mathrm{C}, 66^{\circ} \mathrm{C}$ & - & - & - \\
\hline Rods with/without spheroids & Close to source, grey mat, $75^{\circ} \mathrm{C}$ & + & - & $61 \cdot 2 \pm 0 \cdot 7$ \\
\hline Rods, filaments & Side of run-off channel, red mat, $65^{\circ} \mathrm{C}$ & - & - & - \\
\hline Rods, filaments & Run-off channel, green mat, $57^{\circ} \mathrm{C}$ & - & - & - \\
\hline No growth & Run-off channel, brown mat, $52^{\circ} \mathrm{C}$ & NG & NG & NG \\
\hline \multicolumn{5}{|l|}{ Enrichment culture from RN 132} \\
\hline Rods & Sediment sample, $60^{\circ} \mathrm{C}$ & - & + & $65 \cdot 6$ \\
\hline
\end{tabular}

CY5 $1046+$ and $0 \cdot 16 \mu \mathrm{M}$ FITC-labelled specific probe. It was necessary to lower the concentration of the FITClabelled probes from the $0 \cdot 2 \mu \mathrm{M}$ recommended by Idaho Technology so as to bring the initial fluorescence reading within the scale (6-10) of the LightCycler. Reactions were loaded into glass capillary tubes and snap-sealed using plastic caps (part 1720; Idaho Technology). The PCR cycle was as follows: initial denaturation at $94{ }^{\circ} \mathrm{C}$ for $15-30 \mathrm{~s}$ followed by $30-45$ cycles of denaturation at $94^{\circ} \mathrm{C}$ for between $0 \mathrm{~s}$ and combined annealing at between 50 or $55^{\circ} \mathrm{C}$ for $20-30 \mathrm{~s}$ and extension at $72^{\circ} \mathrm{C}$ for $30 \mathrm{~s}$. The temperature transition rate was set at $20^{\circ} \mathrm{C} \mathrm{s}^{-1}$. Acquisitions of fluorescence signals were carried out at the end of every annealing step for $100 \mathrm{~ms}$ from up to 24 samples. Temperature curves for the release of hybridized fluorogenic probes were obtained immediately after PCR, by increasing the temperature linearly from 45 to $94{ }^{\circ} \mathrm{C}$ at a rate of $0.2^{\circ} \mathrm{C} \mathrm{s}^{-1}$ over a 2 min period with signal acquisition mode set to continuous. A PC and software accompanying the LightCycler provided an interface for the operation and for analysis of the results. Cycle-to-cycle fluorescence emission readings were plotted on the computer screen for continuous monitoring of PCR products. At the end of each run, experimental data were saved to text files that could be analysed with the software provided or imported into a spreadsheet program for normalization or presentation. The effect of sample-tosample variation was minimized by normalization of raw fluorescence data. This was achieved by subtracting the 
minimum value from all data points, dividing the result by the maximum value and multiplying by 100 . Replicate samples with different DNA concentrations prepared by different DNA extraction methods were used and variation in the $T_{\mathrm{m}}$ from run to run was observed in some cases. Therefore, the $T_{\mathrm{m}}$ values are reported as being within a range rather an absolute value. The generation of PCR amplicons was verified by removing the reaction mixtures from the capillary tubes and electrophoresis on a $1.5 \%(\mathrm{w} / \mathrm{v})$ agarose in Tris/acetate/EDTA buffer. A $\lambda$ phage DNA HindIII digest (Promega) was used as a size marker.

\section{RESULTS AND DISCUSSION}

\section{Design of PCR primers and adjacent hybridization probes}

A stretch of nucleotides from positions 1026 to 1076 was identified as a suitable target region for the development of fluorescent hybridization probes. Within this stretch, the nucleotides from position 1046 to 1076 were conserved across most members of domain Bacteria and the upstream region, from position 1026 to 1044, was variable and hence suitable for the development of FITC probes for genus and/or species differentiation (Fig. 1). A universal Cy5labelled probe CY5 $1046+$ (5'-Cy5-AGGTGITGCATGGTIGTCGTCAGCTCGTGT-PO ${ }_{4}-3^{\prime}$ ), capable of binding to the conserved region, and two FITClabelled probes, Fervi (5'-CCGCAAGGTAGGGAGCCAGCA-FITC-3') and Calo (5'-GCCCTTGGGGGAACGGTGAGA-FITC-3'), respectively specific for binding to the variable nucleotide regions for members of the genera Fervidobacterium and Caloramator, were developed. Results from BLAST analysis against the GenBank database, release 125, indicated that the probe CY5 1046+ was specific to most members of domain Bacteria and that probes Fervi and Calo were respectively specific to members of Fervidobacterium and Caloramator.

A forward primer, F1 (5'-CTCCTACGGGAGGCAGCAG-3', positions 339-357), and a reverse primer, R5 (5'-GGGGTTGCGCTCGTTG-3', positions 1115-1100), which straddled the fluorophore probe hybridization site between positions 1026 and 1076, were chosen as PCR amplification primers. Primers F1 and R5 bind to conserved regions of the $16 \mathrm{~S}$ rDNA of members of domain Bacteria and produce an amplicon of approximately $776 \mathrm{bp}$. The theoretical $T_{\mathrm{m}}$ values of $0.5 \mu \mathrm{M}$ of primers $\mathrm{F} 1$ and $\mathrm{R} 5$ when reconstituted in $50 \mathrm{mM}$ monovalent cations were respectively calculated to be 64 and $56^{\circ} \mathrm{C}$. The theoretical $T_{\mathrm{m}}$ values of probes Fervi and Calo under the same conditions were respectively calculated to be 60 and $67{ }^{\circ} \mathrm{C}$. Therefore, the $T_{\mathrm{m}}$ values of the fluorogenic probes were higher than those of the amplification primers, enabling the probes to hybridize to the target regions of the amplicons during the annealing/ extension segment of each PCR cycle, resulting in an increase in $\mathrm{Cy} 5$ fluorescence emission (F2) with a concomitant decrease in fluorescein emission $(\mathrm{F} 1)$ and measured as a ratio of $\mathrm{F} 2: \mathrm{F} 1$.

\section{Real-time detection assay with pure cultures}

An increase in fluorescence was observed with DNA preparations (CTAB-purified DNA or crude DNA prepared by the simple lyse-boil method) for Calora-

(a)
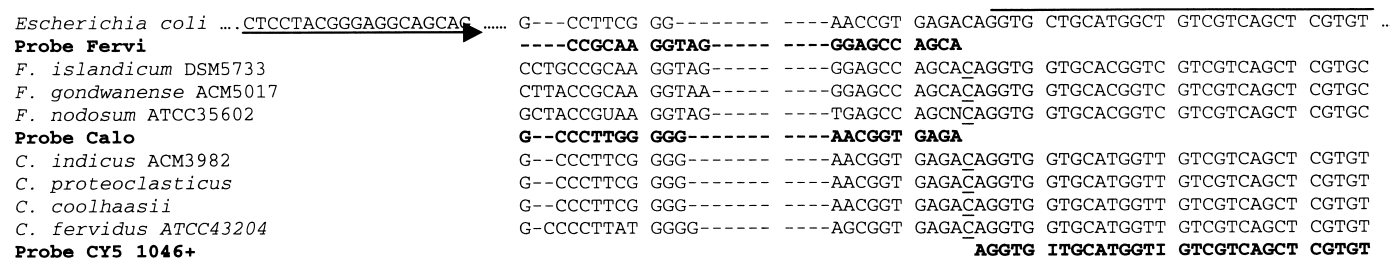

(b)

Schematic Representation

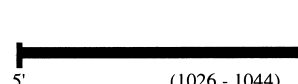

(1026 - 1044)
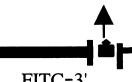

FITC-3'

$(1046-1076)$

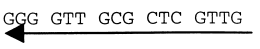

Fig. 1. (a) Nucleotide stretch from positions 1026 to 1076 within the $16 \mathrm{~S}$ rRNA gene suitable for the development of adjacent fluorescent hybridization probes for the detection and identification of thermoanaerobic members of the genera Fervidobacterium and Caloramator using real-time PCR. The primer pair F1 (positions 339-357, $\rightarrow$ ) and R5 (positions $1115-1100, \leftarrow$ ) produces amplicons of approximately $770 \mathrm{nt}$. The amplicon straddles the target (positions 1046-1076) for the universal, degenerate, Cy5-labelled oligonucleotide probe CY5 1046 + and an upstream genus/species target (positions 1026-1044) for FITC-labelled oligonucleotide probes, the two primers being separated from each other by a single nucleotide, C at position 1045. During hybridization, the 3'-FITC probe serves as a donor in fluorescence resonance energy transfer (FRET) to the adjacent 5 -labelled Cy5 acceptor probe, resulting in the emission of fluorescence, which is measured in a LightCycler. The labelling of the $3^{\prime}$ ends with FITC for the FITC probes and the blocking of the $3^{\prime}$ end by phosphorylation for the Cy5 probe stops extension during PCR. Dashes indicate alignment gaps introduced for other members of domain Bacteria during probe design. (b) A schematic representation of (a) showing primer-binding sites (arrows), probe-binding sites (bars) and the single nucleotide separating the two probes (indicated by the up arrow). Positions in (a) and (b) are numbered in accordance with the scheme proposed for the $E$. coli 165 rRNA (Winker \& Woese, 1991). 

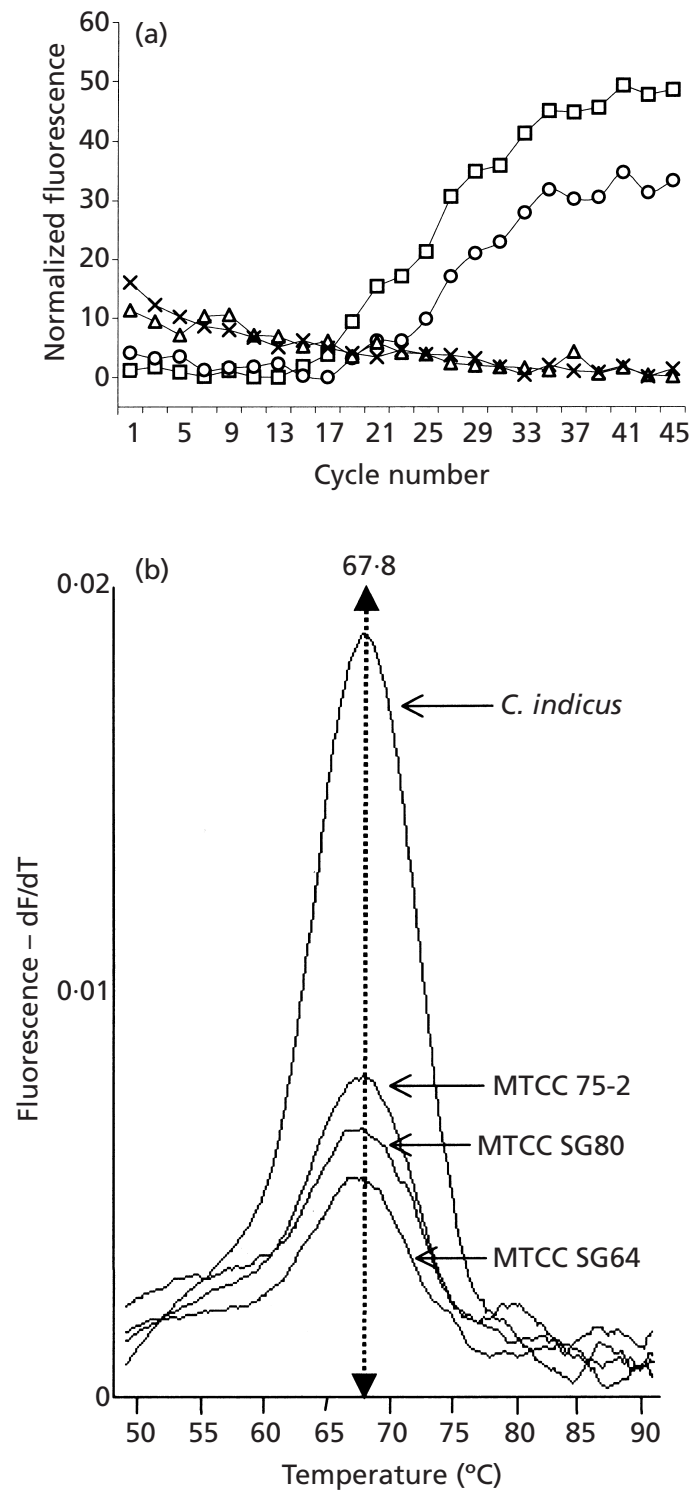

Fig. 2. (a) Increases in fluorescence during specific hybridization of the probes Calo and CY5 1046 + to the target sites in the $16 \mathrm{~S}$ rDNA of Caloramator strain MTCC SG75-2 during PCR, as measured in a LightCycler. Purified DNA was prepared using CTAB $(\square)$ and crude DNA was prepared by the lyse-boil method (O). E. coli DNA $(\triangle)$ and $F$. nodosum DNA $(\times)$ prepared by the lyse-boil method were used as negative controls. (b) Melting curves, generated from the disassociation of the fluorescent probes from C. indicus ACM $3982^{\top}$ and pure cultures of Caloramator strains MTCC 75-2, MTCC SG80 and MTCC SG64, show a $T_{\mathrm{m}}$ of $67 \cdot 8^{\circ} \mathrm{C}$.

mator strain MTCC SG75-2 (Fig. 2a) and Caloramator indicus ACM $3982^{\mathrm{T}}$, but not with the negative controls E. coli $\mathrm{K} 12$ and Fervidobacterium nodosum ATCC $35602^{\mathrm{T}}$, in the presence of probes Calo and CY5 $1046+$ (Fig. 2a). Similar results were obtained with DNA preparations of $F$. nodosum ATCC $35602^{\mathrm{T}}$, Fervidobacterium gondwanense ACM $5017^{\mathrm{T}}$ and Fervidobacterium islandicum DSM 5733 ${ }^{\mathrm{T}}$, but not with the negative controls E. coli K12, Dictyoglomus thermo- philum ATCC $35947^{\mathrm{T}}$ and Thermoanaerobacter thermohydrosulfuricus DSM $567^{\mathrm{T}}$, in the presence of probes Fervi and CY5 1046+. The initiation of increase in fluorescence was DNA concentration dependent and could be detected as early as cycle 10 with higher concentrations of DNA (e.g. $6 \mathrm{ng}$ ) and at cycle 29 with low DNA concentrations (e.g. 6 fg) (Spanevello, 2001). A $776 \mathrm{bp}$ PCR product was always amplified from all DNA preparations, including those from negative-control cultures, and observed on agarose gels. This was expected and is a result of amplification from the binding of universal bacteriaspecific primers to all template DNA. However, an increase in fluorescence was not observed from the negative controls, since the PCR product possessed the binding site for the universal probe CY5 $1046+$ but lacked the hybridization site for specific FITC probes, and this is in line with our expectations.

Immediately following the completion of real-time PCR, the PCR products were melted by a continuous gradual and uniform increase in temperature from 50 to $95^{\circ} \mathrm{C}$, resulting in the disassociation of the fluorescent probe, from which the probe $T_{\mathrm{m}}$ was calculated. The $T_{\mathrm{m}}$ for Caloramator strain MTCC SG75-2 and $C$. indicus ACM $3982^{\mathrm{T}}$ was determined to be $66 \pm 2{ }^{\circ} \mathrm{C}$ (Fig. 2b). Similar results can be expected for the other members of the genus Caloramator, which currently includes Caloramator fervidus ATCC $43204^{\mathrm{T}}$, previously known as Clostridium fervidus (Patel et al., 1987), Caloramator proteoclasticus DSM $10124^{\mathrm{T}}$ (Tarlera et al., 1997) and Caloramator coolhaasii DSM $12679^{\mathrm{T}}$ (Plugge et al., 2000), as their target sequences are identical to that of $C$. indicus ACM $3982^{\mathrm{T}}$ (Fig. 1). Probe-to-target sequence mismatch can assist in distinguishing between species, as mismatches can produce a significant difference in the $T_{\mathrm{m}}$ of melting curves. It was therefore expected that the $T_{\mathrm{m}}$ values for all three Fervidobacterium species would be different, as the Fervi probe and $F$. islandicum DSM $5733^{\mathrm{T}}$ target sequence were identical but there was one nucleotide mismatch with $F$. nodosum ATCC $35602^{\mathrm{T}}$ and two nucleotide mismatches with $F$. gondwanense ACM $5017^{\mathrm{T}}$. The $T_{\mathrm{m}}$ for $F$. islandicum DSM $5733^{\mathrm{T}}$ was determined to $61.7 \pm 0.5^{\circ} \mathrm{C}$ and was substantially higher than the values of $55.8 \pm 1.7{ }^{\circ} \mathrm{C}$ for $F$. nudism ATCC $35602^{\mathrm{T}}$ and $F$. gondwanense ACM $5017^{\mathrm{T}}$. This inconsistency between the experimental data and expected result may be due to errors in the sequences of Fervidobacterium species, but could also be due to the unpredicted binding properties of fluorescent hybridization probes in real-time PCR assay.

\section{Detection and identification of Caloramator and Fervidobacterium strains from the MTCC}

The real-time PCR assay was used successfully to identify Caloramator and Fervidobacterium species from 14 randomly chosen cultures isolated previously from the Great Artesian Basin of Australia and stored with the Griffith University MTCC (Table 1). Of these, two strains (MTCC SG64 and MTCC SG76) were 
identified as Caloramator, four (MTCC AB18, MTCC $\mathrm{AB} 19, \mathrm{MTCC} \mathrm{AB} 20$ and MTCC SG58) as members of the $F$. nodosum- $F$. gondwanense group and a further strain (MTCC SG80) was found be a mixed culture composed of members of Caloramator and the $F$. nodosum-F. gondwanense group. Re-examination of the mixed culture MTCC SG80 under a phase-contrast microscope indicated that only some cells had the typical terminal protuberances, termed spheroids, characteristic of Fervidobacterium, whereas others were non-spheroid-bearing, morphologically larger, atypical rods. The fine distinction between the two morphotypes could have been missed easily during culture purification procedures of the isolate. We believe that the method reported here could be useful for routine or random purity checks of strains in culture collections, as pure cultures have sometimes been reported to be mixed (Erbeznik et al., 1997). The remaining seven strains were not identifiable as Caloramator and Fervidobacterium and were deemed to represent novel species.

\section{TYEG enrichment cultures and their identification}

In our hands, TYEG medium was found to support the growth of a range of known and unidentified thermophilic anaerobe taxa, including members of Caloramator and Fervidobacterium, that had previously been cultured using a variety of different media (Wynter et al., 1996; Huber et al., 1990; Patel et al., 1985b, 1991). Consequently, TYEG medium was used for initiating enrichments from eight samples collected from the Great Artesian Basin of Australia. Seven of the eight enrichments were positive for growth and grew rapidly $(<48 \mathrm{~h})$ at $60^{\circ} \mathrm{C}$. Six of the positive enrichments consisted of rods and/or filaments, whereas the seventh enrichment initiated from grey mats consisted of rods with terminal spheroids, a morphological trait of Fervidobacterium species (Patel et al., 1985b, 1991) (Table 1). The failure of one of the enrichments to develop is perhaps a reflection of the inability of cells from the low-temperature habitat $\left(52{ }^{\circ} \mathrm{C}\right)$ to grow at a higher temperature $\left(60^{\circ} \mathrm{C}\right)$ and/or the inadequacy of TYEG to support growth.

The real-time PCR assay was used to determine the identity of the seven enrichment cultures. The enrichment culture initiated from the sediment of bore RN 132 was identified as a Caloramator species and the enrichment culture initiated from the grey mat of bore RN 17263 was identified as an F. islandicum-like strain (Table 1). Interestingly, the pure culture MTCC SG75, identified as a strain of Caloramator, had been isolated from the sediment of bore RN 132 some 3 years ago and was again detected in the enrichment culture in our present studies. This indicates the usefulness of the technique for studies on pure and enrichment cultures. The remaining five enrichment cultures not positively identified as Caloramator or Fervidobacterium were deemed to represent novel strains.

\section{Advantages of the method}

$16 \mathrm{~S}$ rDNA is widely used in microbial systematics and taxonomy and over 20000 sequences are available in databases (Maidak et al., 2001; Benson et al., 2000). We have taken advantage of the availability of these databases and have identified a moderately conserved region and an adjacent upstream variable nucleotide region in the $16 \mathrm{~S}$ rDNA for use in a simple and rapid real-time PCR assay. The probe CY5 1046+, which is more expensive to synthesize, was designed by introducing $\mathrm{dI}$ at positions 1051 and 1061 to increase its degeneracy, so that it could act as a universal $16 \mathrm{~S}$ rDNA probe and bind to all members of domain Bacteria, while the FITC probes, which are less expensive to synthesize, would target the adjacent upstream variable region to give the required genusand or species-distinguishing specificity. Consequently, by simply replacing the FITC probes that target approximately position 1026 and ensuring that the theoretical $T_{\mathrm{m}}$ of the new probes is $3-10^{\circ} \mathrm{C}$ higher than the amplification primers, it will be possible to detect and identify members of domain Bacteria. We have recently synthesized FITC-labelled specific probes for the pathogens Campylobacter and Arcobacter species and used these successfully for their identification in conjunction with probe CY5 1046+ (M. Abu-Hallaweh and B. K. C. Patel, unpublished). Therefore, we believe that this simple approach will not only save costs for probe synthesis but will also save considerable time, as it will be unnecessary to apply the time-consuming and complex rules of probe design every time a FITC probe is developed.

We have developed two specific probes for identifying members of the genera Caloramator and Fervidobacterium and tested them experimentally on pure cultures and enrichment cultures using the real-time PCR assay. The results suggests that a vast majority of the cultures from the Griffith University MTCC collection and from the enrichments are not members of Caloramator or Fervidobacterium, but may be other thermoanaerobes such as Thermoanaerobacter or novel taxa. It will therefore be necessary to develop additional complementing probes for known thermophilic anaerobic taxa. Once this is achieved, it will be possible to identify novel microbes rapidly from culture collections and/or enrichment cultures. The real-time PCR has the further advantage that it lends itself to quantification. We are currently developing the technique further for quantifying Fervidobacterium and Caloramator directly in environmental sample DNA. This will provide direct evidence of their presence, numbers and diversity in different habitats.

A bottleneck for molecular methods is the timeconsuming step of preparing pure DNA, which is generally regarded as necessary for PCR. However, in the real-time PCR assay reported here, crude DNA was also used, prepared by a simple lyse-boil and centrifuge step, with no adverse outcomes. A similar 
crude DNA extraction procedure for real-time PCR detection of Leptospira species has been reported by us previously (Woo et al., 1997).

\section{ACKNOWLEDGEMENTS}

In part, funding for the work was provided by the Australian Research Council.

\section{REFERENCES}

Amann, R. I., Ludwig, W. \& Schleifer, K. H. (1995). Phylogenetic identification and in situ detection of individual microbial cells without cultivation. Microbiol Rev 59, 143-169.

Andrews, K. T. \& Patel, B. K. C. (1996). Fervidobacterium gondwanense sp. nov., a new thermophilic anaerobic bacterium isolated from nonvolcanically heated geothermal waters of the Great Artesian Basin of Australia. Int J Syst Bacteriol 46, 265-269.

Benson, D. A., Karsch-Mizrachi, I., Lipman, D. J., Ostell, J., Rapp, B. A. \& Wheeler, D. L. (2000). GenBank. Nucleic Acids Res 28, 15-18. Chrisostomos, S., Patel, B. K. C., Dwivedi, P. P. \& Denman, S. E. (1996). Caloramator indicus sp. nov., a new thermophilic anaerobic bacterium isolated from the deep-seated nonvolcanically heated waters of an Indian artesian aquifer. Int J Syst Bacteriol 46, 497-501.

Denman, S., Hampson, K. \& Patel, B. K. C. (1991). Isolation of strains of Thermus aquaticus from the Artesian Basin and a simple and rapid procedure for the preparation of their plasmids. FEMS Microbiol Lett 82, 73-78.

Dunbar, J., White, S. \& Forney, L. (1997). Genetic diversity through the looking glass: effect of enrichment bias. Appl Environ Microbiol 63, 1326-1331.

Erbeznik, M., Jones, C. R., Dawson, K. A. \& Strobel, H. J. (1997). Clostridium thermocellum JW20 (ATCC 31549) is a coculture with Thermoanaerobacter ethanolicus. Appl Environ Microbiol 63, 2949-2951.

Harmsen, H. J. M., Prieur, D. \& Jeanthon, C. (1997). Group-specific 16S rRNA-targeted oligonucleotide probes to identify thermophilic bacteria in marine hydrothermal vents. Appl Environ Microbiol 63, 4061-4068.

Hillier, L. \& Green, P. (1991). OSP: a computer program for choosing PCR and DNA sequencing primers. PCR Methods Appl 1, 124-128.

Huber, R., Woese, C. R., Langworthy, T. A., Kristjansson, J. K. \& Stetter, K. O. (1990). Fervidobacterium islandicum sp. nov., a new extremely thermophilic eubacterium belonging to the "Thermotogales". Arch Microbiol 154, 105-111.

Maidak, B. L., Cole, J. R., Lilburn, T. G. \& 7 other authors (2001). The RDP-II (Ribosomal Database Project). Nucleic Acids Res 29, 173-174.

Patel, B. K. C., Morgan, H. W. \& Daniel, R. M. (1985a). A simple and efficient method for preparing anaerobic media. Biotechnol Lett 7, $227-228$.
Patel, B. K. C., Morgan, H. W. \& Daniel, R. M. (1985b). Fervidobacterium nodosum gen. nov. and spec. nov., a new chemoorganotrophic, caldoactive, anaerobic bacterium. Arch Microbiol 141, 63-69.

Patel, B. K. C., Monk, C., Littleworth, H., Morgan, H. W. \& Daniel, R. M. (1987). Clostridium fervidus sp. nov., a new chemoorganotrophic acetogenic thermophile. Int J Syst Bacteriol 37, 123-126.

Patel, B. K. C., Skerrah, J. H. \& Nichols, P. D. (1991). The phospholipid ester-linked fatty acid composition of thermophilic and extremely thermophilic bacteria. Syst Appl Microbiol 14, 311-316.

Plugge, C. M., Zoetendal, E. G. \& Stams, A. J. M. (2000). Caloramator coolhaasii sp. nov., a glutamate-degrading, moderately thermophilic anaerobe. Int J Syst Evol Microbiol 50, 1155-1162.

Ravot, G., Magot, M., Fardeau, M.-L., Patel, B. K. C., Prensier, G., Egan, A., Garcia, J.-L. \& Ollivier, B. (1995). Thermotoga elfii sp. nov., a novel thermophilic bacterium from an African oil-producing well. Int J Syst Bacteriol 45, 308-314.

Reysenbach, A. L., Wickham, G. S. \& Pace, N. R. (1994). Phylogenetic analysis of the hyperthermophilic pink filament community in Octopus Spring, Yellowstone National Park. Appl Environ Microbiol 60, 2113-2119.

Spanevello, M. D. (2001). The nature and diversity of the microbial communities of the Great Artesian Basin of Australia. PhD thesis, Griffith University, Brisbane, Australia.

Tarlera, S., Muxí, L., Soubes, M. \& Stams, A. J. M. (1997). Caloramator proteoclasticus sp. nov., a new moderately thermophilic anaerobic proteolytic bacterium. Int J Syst Bacteriol 47, 651-656.

Wilson, K. (1987). Preparation of genomic DNA from bacteria. In Current Protocols in Molecular Biology, pp. 2.4.1-2.4.5. Edited by F. Ausubel, R. Brent, R. Kingston, D. Moore, J. Seidman, J. Smith \& K. Struhl. New York: Greene and Wiley-Interscience.

Winker, S. \& Woese, C. R. (1991). A definition of the domains Archaea, Bacteria and Eucarya in terms of small subunit ribosomal RNA characteristics. Syst Appl Microbiol 13, 161-165.

Wittwer, C. T., Ririe, K. M., Andrew, R. V., David, D. A., Gundry, R. A. \& Balis, U. J. (1997). The LightCycler: a microvolume multisample fluorimeter with rapid temperature control. Biotechniques 22, 176-181.

Woo, T. H. S., Patel, B. K. C., Smythe, L. D., Symonds, M. L., Norris, M. A. \& Dohnt, M. F. (1997). Identification of pathogenic Leptospira genospecies by continuous monitoring of fluorogenic hybridization probes during rapid-cycle PCR. J Clin Microbiol 35, 3140-3146.

Woo, T. H. S., Patel, B. K. C., Smythe, L. D., Norris, M. A., Symonds, M. L. \& Dohnt, M. F. (1998a). Identification of pathogenic Leptospira by TaqMan probe in a LightCycler. Anal Biochem 256, 132-134.

Woo, T. H. S., Patel, B. K. C., Smythe, L. D., Symonds, M. L., Norris, M. A., Weyant, R. S. \& Dohnt, M. F. (1998b). Identification of Leptospira inadai by continuous monitoring of fluorescence during rapid cycle PCR. Syst Appl Microbiol 21, 89-96.

Wynter, C. V. A., Galea, C. F., Cox, L. M., Dawson, M. W., Patel, B. K. C., Hamilton, S., De Jersey, J. \& Inkerman, P. A. (1995). Thermostable dextranases: screening, detection and preliminary characterization. J Appl Bacteriol 79, 203-212.

Wynter, C., Patel, B. K. C., Bain, P., De Jersey, J., Hamilton, S. \& Inkerman, P. A. (1996). A novel thermostable dextranase from a Thermoanaerobacter species cultured from the geothermal waters of the Great Artesian Basin of Australia. FEMS Microbiol Lett 140, 271-276. 